\title{
Genetic relatedness and taxonomy in closely related species of Hedysarum (Fabaceae)
}

Natalia S.

nszvyagina@mail.ru

\section{Olga V. Dorogin}

Pilar Catalan ${ }^{\mathrm{b}, \mathrm{c}}$

${ }^{a}$ Central Siberian Botanical Garden of the Siberian Brunch of the Russian Academy of Sciences, Zolotodolinskaya st. 101, 630090, Novosibirsk, Russia

${ }^{\mathbf{b}}$ Department of Botany, Institute of Biology, Tomsk State University, Lenin Av. 36, 634050, Tomsk, Russia

'Department of Agricultural and Environmental Sciences, High Polytechnic School of Huesca, University of Zaragoza, Ctra. Cuarte km 1, E22071, Huesca, Spain

${ }^{*}$ Corresponding author

\section{Abstract}

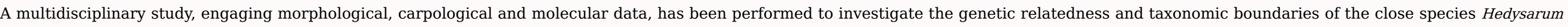

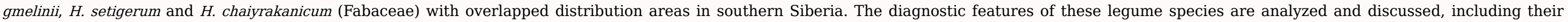

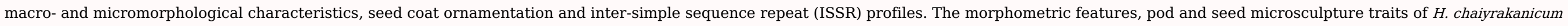

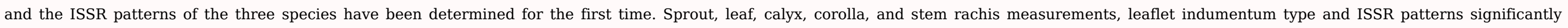

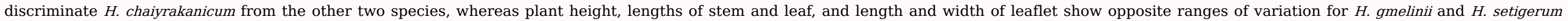

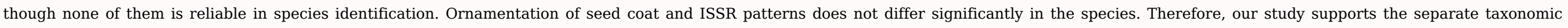
treatment of $H$. chaiyrakanicum and the subordination of the cryptic species $H$. setigerum within $H$. gmelinii.

Keywords: Hedysarum gmelinii complex; Genetic relationships; ISSR markers; Morphology; Seed coat pattern; Molecular taxonomy

\section{Introduction}

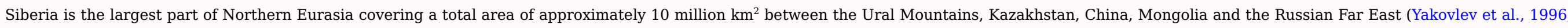

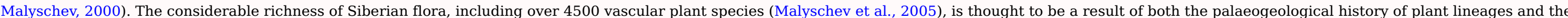

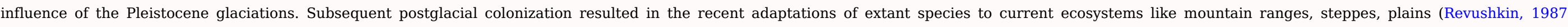
Malyschev, 2000). According to Takhtadjan (1986), Holarctic Siberia includes the Circum-Boreal, Irano-Turanian and a part of the Western Asian floristic regions.

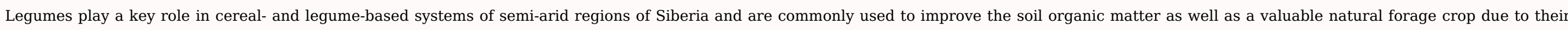

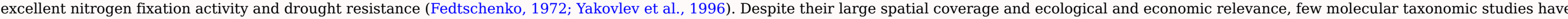
been conducted on Siberian legumes.

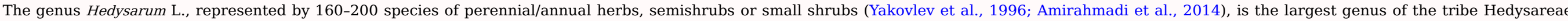

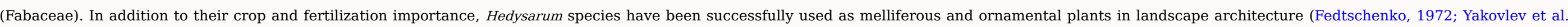

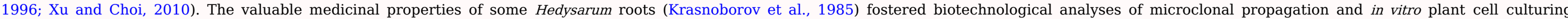
(Vdovitchenko et al., 2007; Erst et al., 2015). 


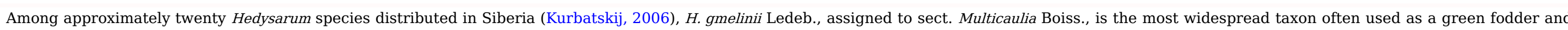

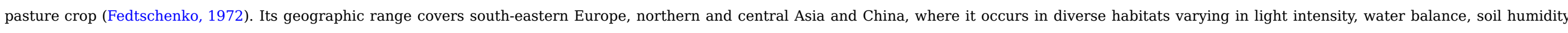

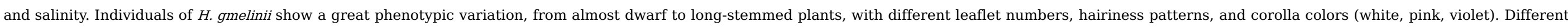

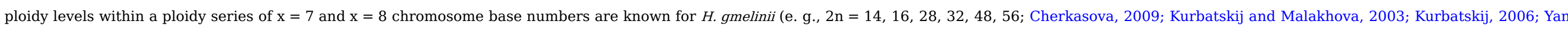
et al., 1989). The varying morphological and karyological characteristics led to a highly complex taxonomic identification of cryptic species or intraspecific taxa within the $H$. gmelinii group.

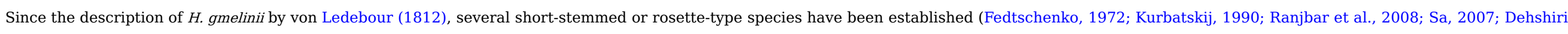

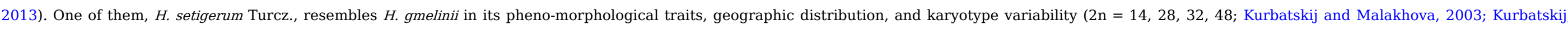

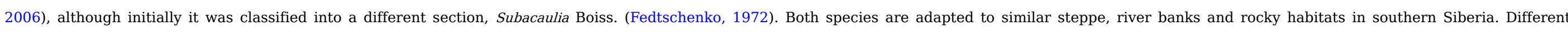

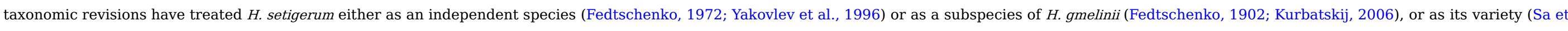

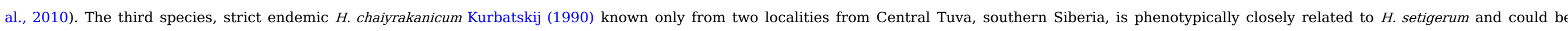

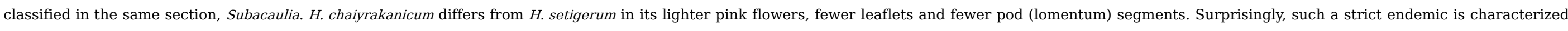
by two chromosome numbers, $2 \mathrm{n}=14$ and 16 (Zvyagina et al., 2016), measured in individuals from a single population (Khairakan Mountain).

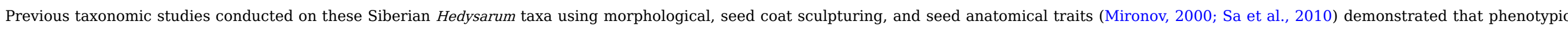

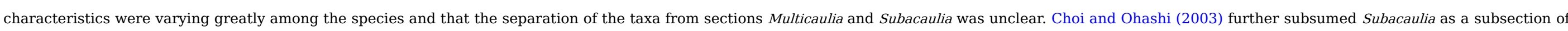
sect. Multicaulia based on the similar type of morphological (habit, flowers, seeds, pollen) and anatomical characteristics.

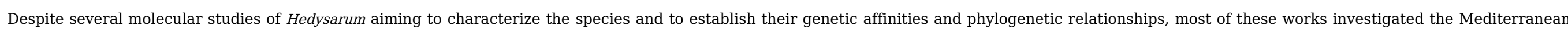

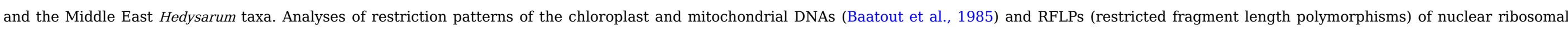

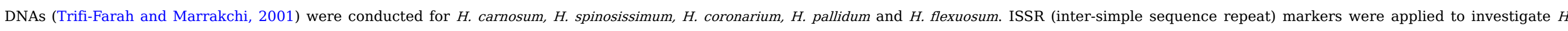

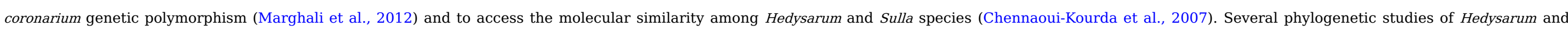

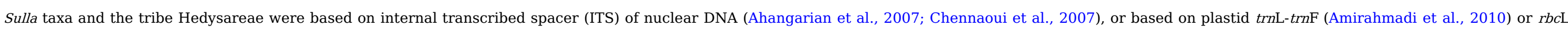

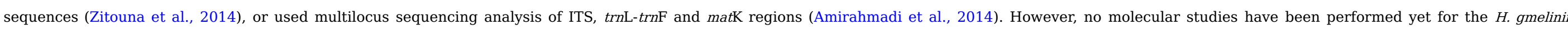
complex.

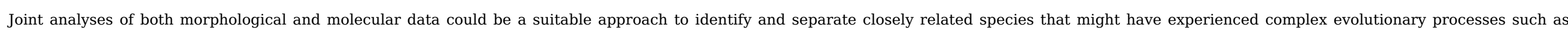

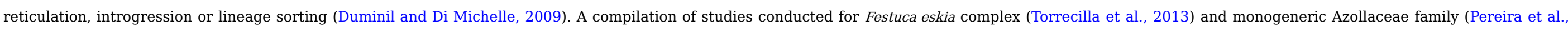

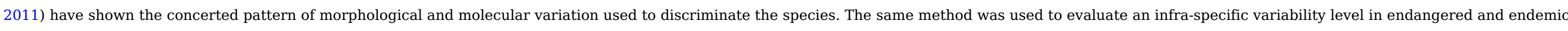

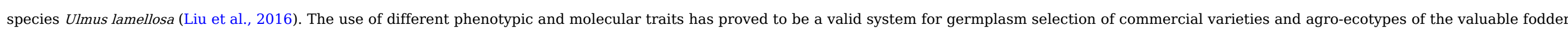
legume H. coronarium (Flores et al., 1997) and for assessment of the relatedness between its wild accessions (Ruisi et al., 2011).

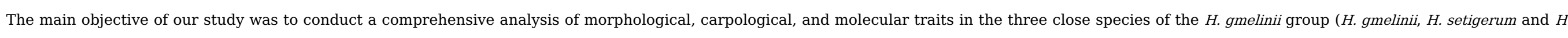
chaiyrakanicum) aiming to evaluate the genetic relatedness among the species and to outline their taxonomic delimitation.

\section{Materials and methods}

\subsection{Plant material}

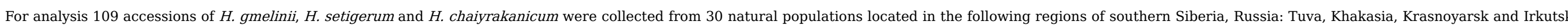

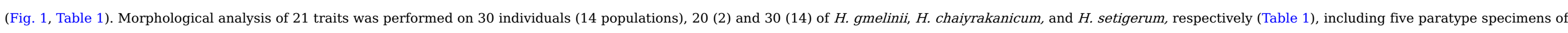

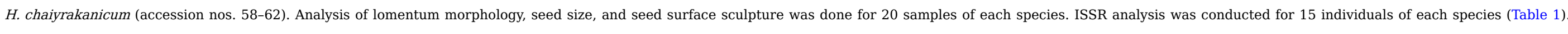

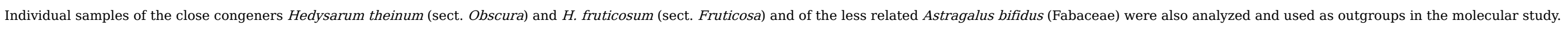




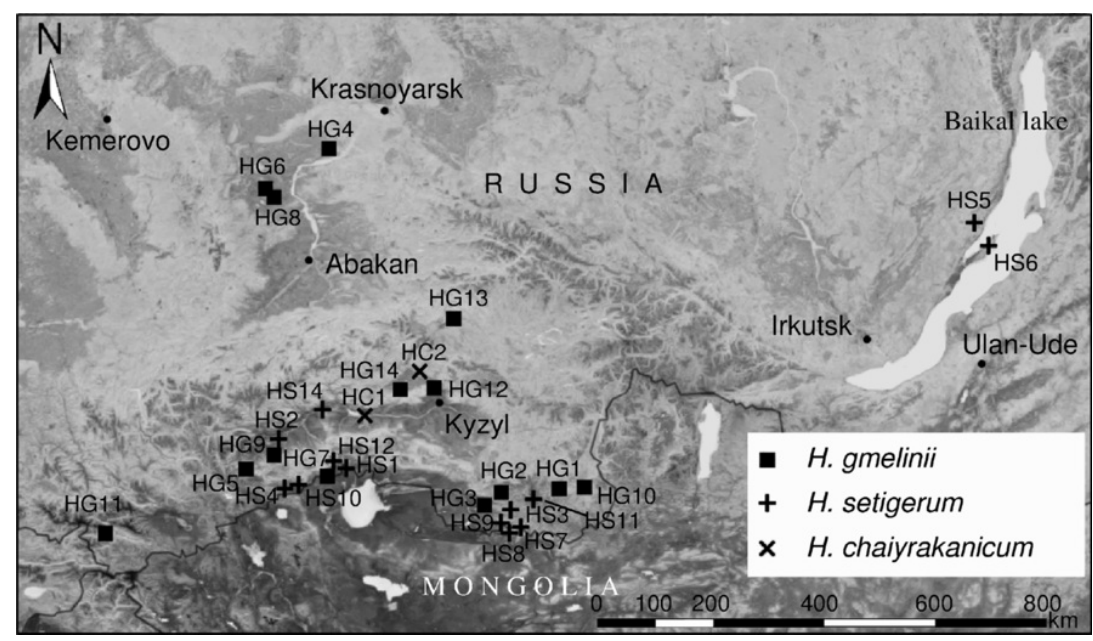

Fig. 1 Geographical distribution of the studied taxa of the Hedysarum gmelinii complex in southern Siberia. Symbols map the sampled localities of the studied populations of each taxon (see Table 1). alt-text: Fig. 1

Table 1 Origins of specimens examined in the phenotypic and molecular study of $H$. gmelinii group species (southern Siberia, Russia). Ind. No., individual number alt-text: Table 1

Population code Location, collectors' names, year of collection

\section{H. gmelinii}

HG1

HG2

HG3

HG4

HG5

HG6

HG7

HG8

HG9

HG10

SW Tuva, Tchirgalandy $50^{\circ} 28^{\prime} \mathrm{N} 97^{\circ} \mathrm{E}$; Sobolevskaya K.A., Sergeeva A. 1946

$1-2$

S Tuva, Naryn; Krasnoborov I.M., Kosinetz L. 1972

$3-5$

S Tuva, Naryn; Krasnoborov I.M., Kosinetz L. 1972

6-8

Krasnoyarsk region, Primorsk; Pavlova G., Kilyn F. 1973

9

C Tuva, Khendelen; Koroleva A., Gontcharova E. 1976

10

N Khakasia, Shira lake; Zvyagina N., Artemov I. 2011

11-15

C Tuva, Sap pass $50^{\circ} 44^{\prime} \mathrm{N} 91^{\circ} 50^{\prime} \mathrm{E}$; Zvyagina N., Artemov I. 2011

N Khakasia, Tzelinny 54³4.402'N 8954.183'E; Zvyagina N., Artemov I. 2011

$24-31$

W Tuva, Tsagan-Shibety range $50^{\circ} 46.742^{\prime} \mathrm{N} 90^{\circ} 11.703^{\prime} \mathrm{E}$; Artemov I. 2007

$32-33$

C Tuva, Tere-Khol lake 50 $36^{\prime} \mathrm{N} 97^{\circ} 25^{\prime} \mathrm{E}$; Artemov I. 2007

$34-35$

S Tuva, Katunsky range $49^{\circ} 42^{\prime} \mathrm{N} 87^{\circ} 12^{\prime} \mathrm{E}$; Artemov I., Kosterin O. 1988

$36-37$

C Tuva, the mouth of the Ujuk river $52^{\circ} 06^{\prime} \mathrm{N} 94^{\circ} 15^{\prime} \mathrm{E}$; Schaulo D., Krasnikov A. 1987

C Tuva, Ujuksky range, Germanovka; Lomonosova M., Kosinetz L. 1971

HG13

C Tuva, Kurtushibinsky range, Khut; Schaulo D., Nalpina T. 1980 
C Tuva, Khairakan Mountain $51^{\circ} 30^{\prime} \mathrm{N}, 92^{\circ} 55^{\prime}$ E. Schaulo D. 1989

C Tuva, Khairakan Mountain, 51 ${ }^{\circ} 34.474^{\prime} \mathrm{N}, 93^{\circ} 03.784^{\prime} \mathrm{E}$ Zvyagina N., Artemov I. 2011

C Tuva, Khairakan Mountain; Timokhina S., Egorova G. 1974

C Tuva, Khairakan Mountain, SE slope; Selyutina I.Yu. 2006

\subsection{Morphological analysis}

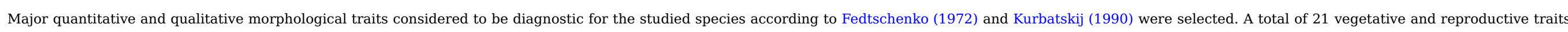

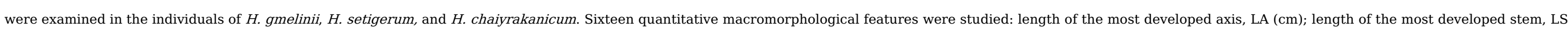

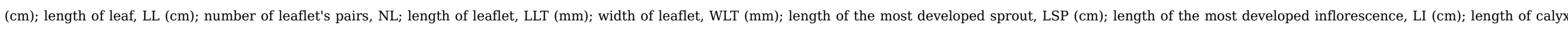

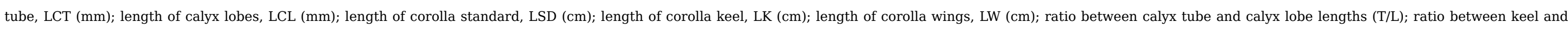
standard lengths (K/S); and ratio between wings and keel lengths $(\mathrm{W} / \mathrm{K})$.

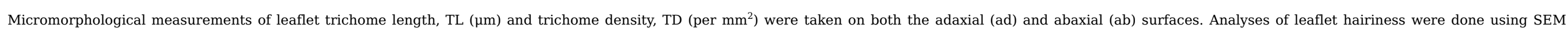
(Hitachi T-1000). Before scanning, specimens were softened by keeping them in Petri dishes containing moistened cotton pellet. 


\subsection{Carpological analysis}

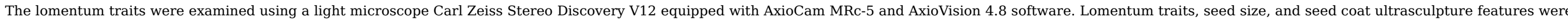

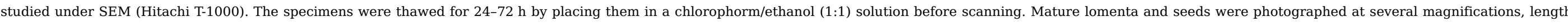
and width of lomentum segments (SGL, SGW) and seeds (SL, SW) were measured and seed coat ornamentation was inspected.

\subsection{DNA extraction and ISSR assay}

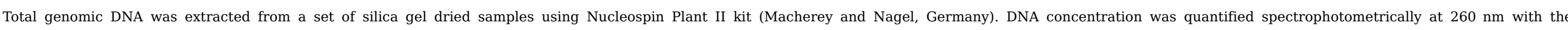
BioPhotometer (Eppendorf, Germany) and its qualities were estimated from the $A_{260} / A_{280}$ ratio.

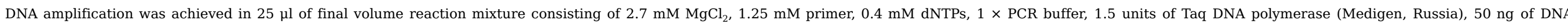

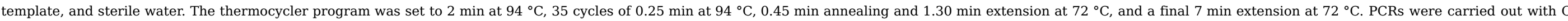

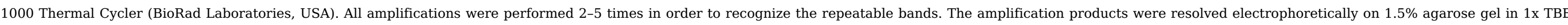

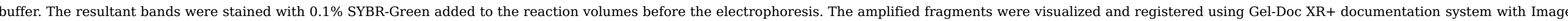
Lab Software (Bio-Rad Laboratories, USA).

\subsection{Statistical and genetic analyses}

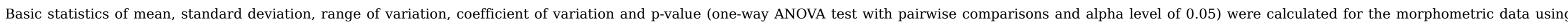
PAST software (Hammer et al., 2001). Total deviation was measured as a sum of deviations.

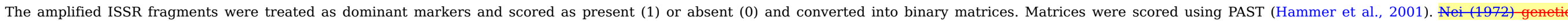

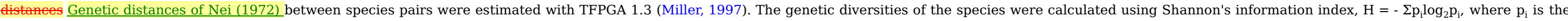

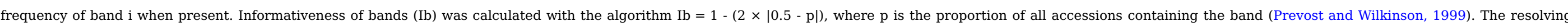
power ( $\mathrm{Rp})$ of each primer was determined according to the formula: $\mathrm{Rp}=\Sigma \mathrm{Ib}$

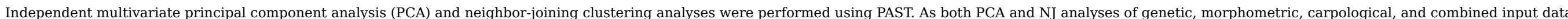
sets gave congruent clusters, we present the results of PCA conducted for separated and joined data sets, and a NJ dendrogram based on ISSR data as the most informative one.

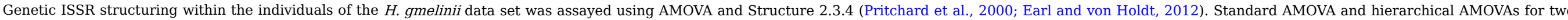

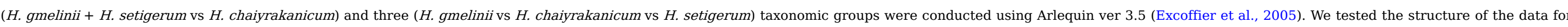

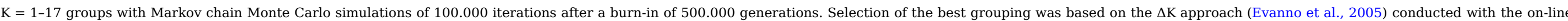
application Structure Harvester.

\section{Results}

\subsection{Morphological trait variability}

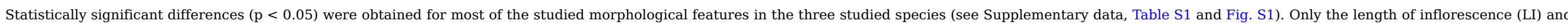
the ratios between calyx tube and lobes (T/L) and between corolla keel and standard (K/S) did not differ significantly (Fig. S2).

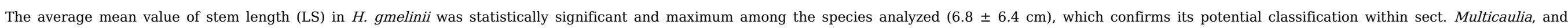

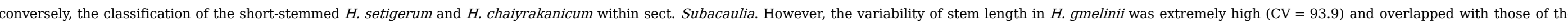
other studied taxa in some individuals (e.g., individuals 36 and 37, from the same population (HG3) had stems of 0.5 and 7 cm long, respectively).

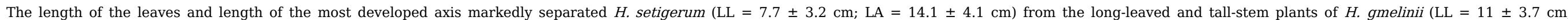



$9 \times 3.9 \mathrm{~mm}$ ).

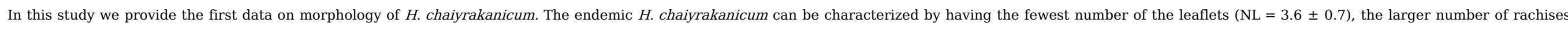

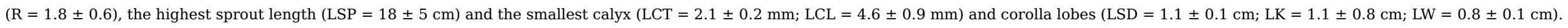

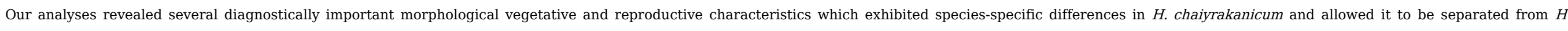

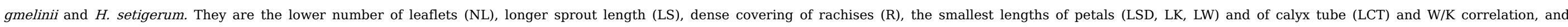

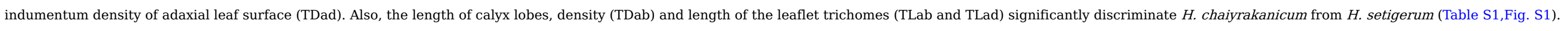

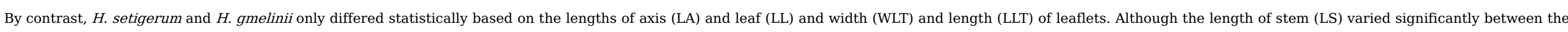

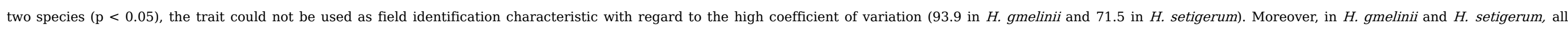
reproductive characteristics varied similarly (Table S1) and could not be treated as a sufficient data source to discriminate the species.

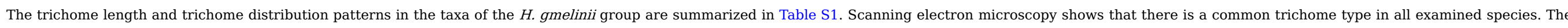

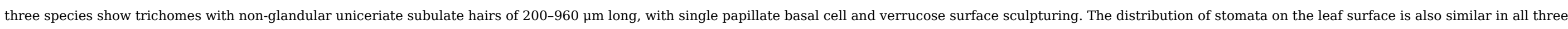
taxa. The stomata are paracytic, surrounded by (3) 5-7 epidermal cells, placed in a sunken position; they occur on the surface of both adaxial and abaxial sides, being more abundant in less haired plants.

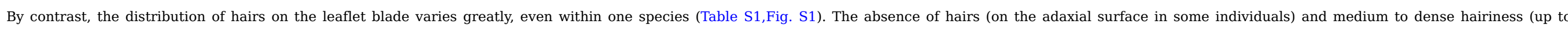

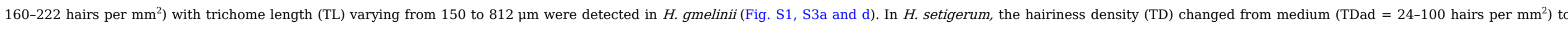

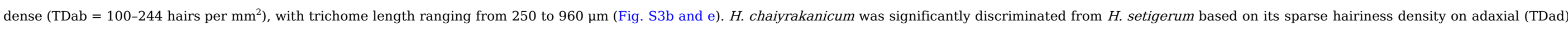

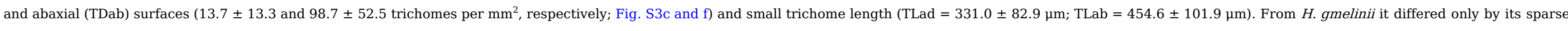
hairiness density on the adaxial leaflet surface (TDad).

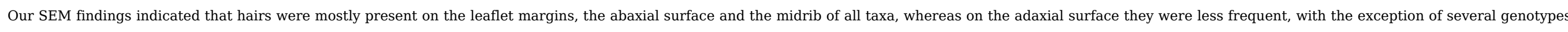

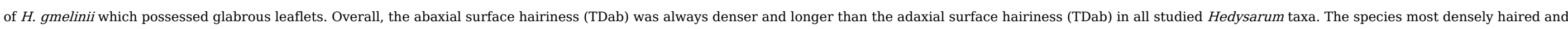
with the longest trichomes on both adaxial and abaxial leaf surfaces was $H$. setigerum.

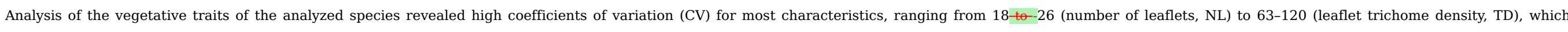

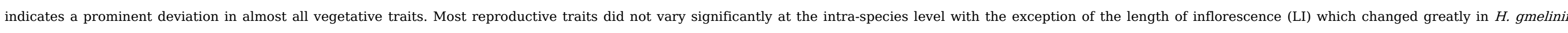

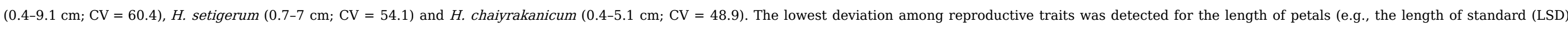

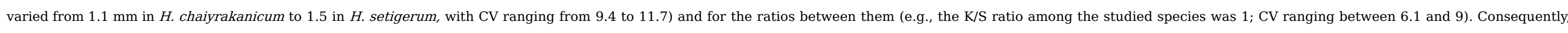
they can be considered as the most constant traits among the studied morphologic characteristics.

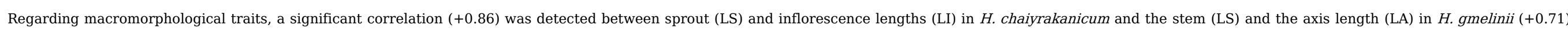

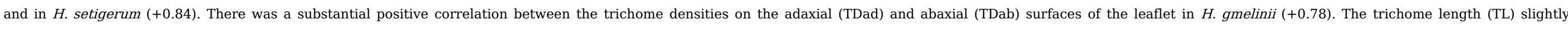
negatively correlated with the indumentum density (TD) on the adaxial $(-0.59)$ and abaxial $(-0.48)$ blade surfaces in H. setigerum.

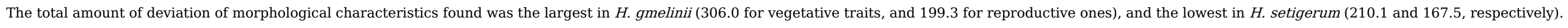

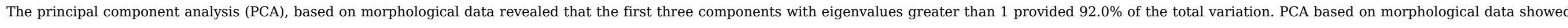
overlapped clusters of samples for the three studied species (Fig. 2a). 


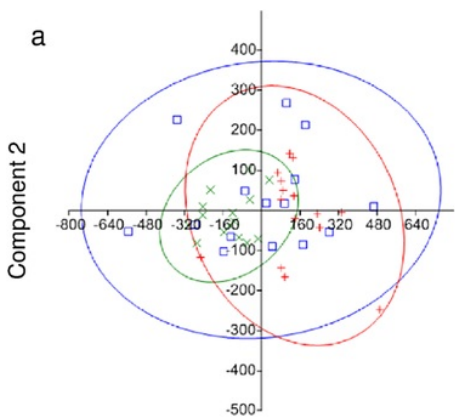

Component 1

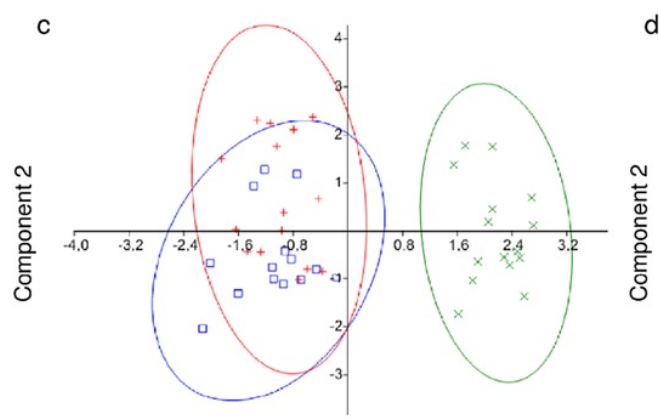

Component 1

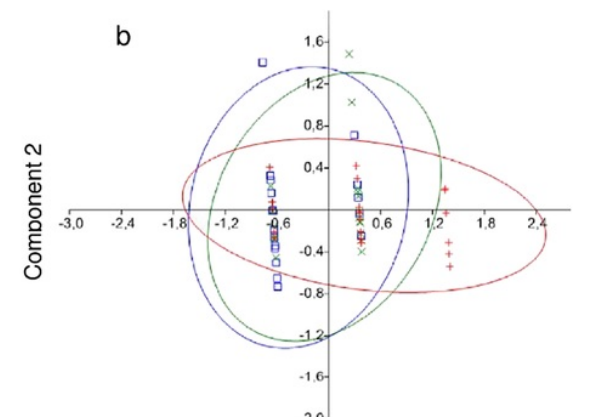

Component 1

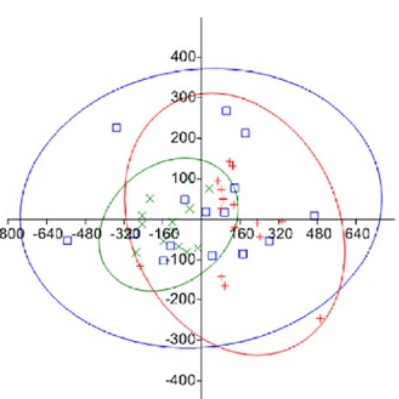

Component 1

\begin{tabular}{|c|c|}
\hline 口 H. gmelinii & H. setigerum \\
\hline
\end{tabular}

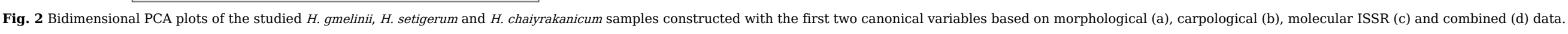
alt-text: Fig. 2

\subsection{Carpological variation}

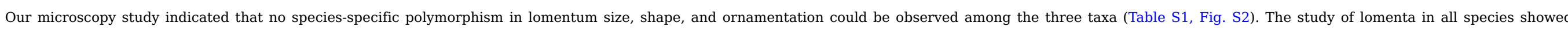

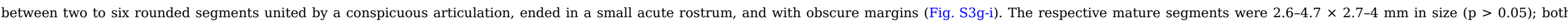

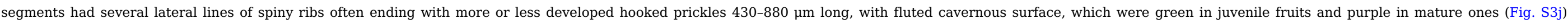

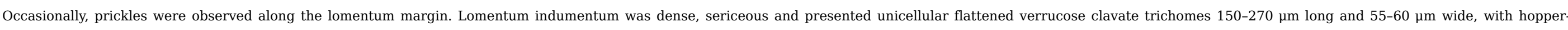

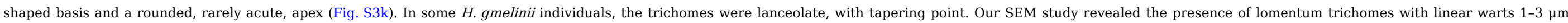

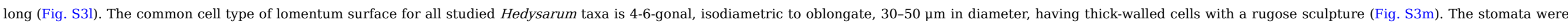

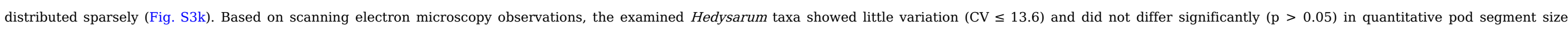
characteristics (segment length, SGL and width, SGW) (Table S1, Fig. S1).

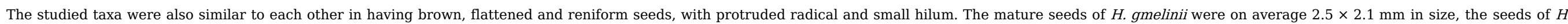

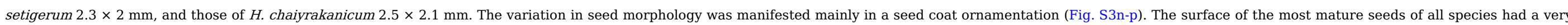

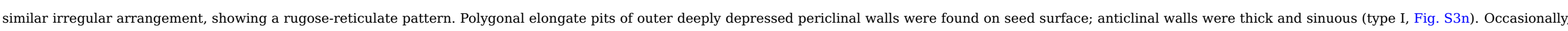

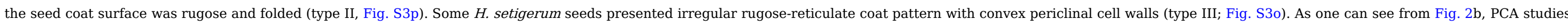
of carpological features did not found a gap for the delimitation of the species. 


\subsection{Molecular diversity}

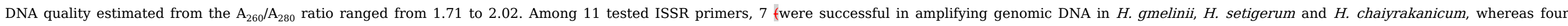
$\left[(\mathrm{CT})_{8} \mathrm{GC},(\mathrm{CA})_{6} \mathrm{~A} / \mathrm{GG},(\mathrm{GA})_{6} \mathrm{CC}\right.$, and $\left.(\mathrm{CA})_{6} \mathrm{AC}\right]$ were omitted from the study because of the weak or unclear amplification pattern or due to the absence of PCR-products (Table 2).

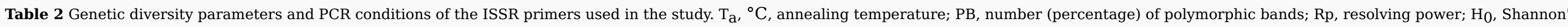
information index.

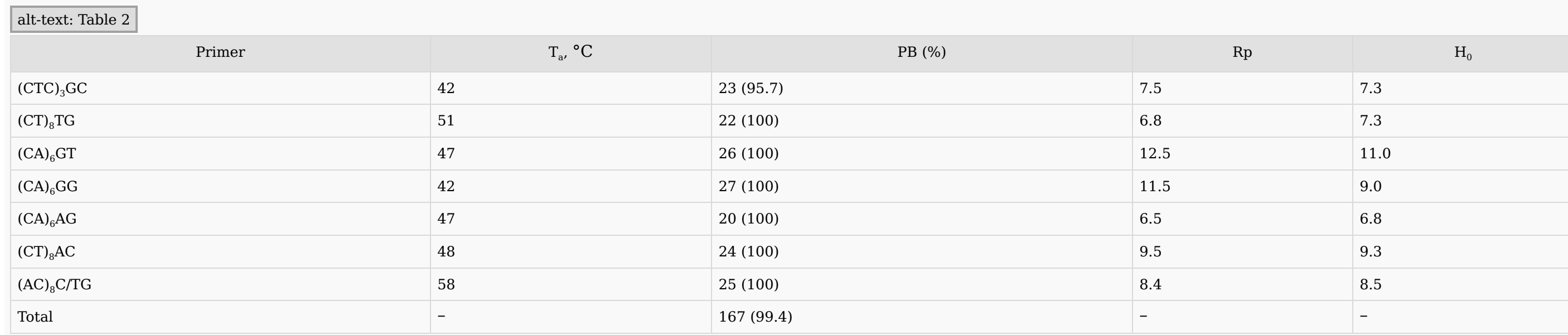

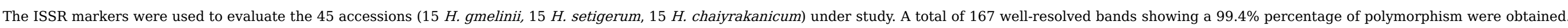

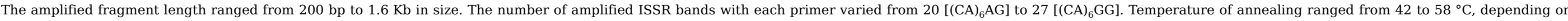

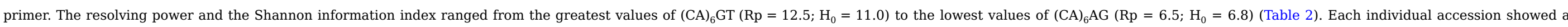
different ISSR profile from all others. Among 167 polymorphic ISSR fragments amplified, 27 bands were characteristic markers (species-specific), but not obligate for the species.

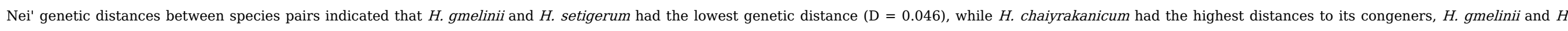
setigerum (D was 0.115 and 0.109, respectively) (Table 3).

Table 3 Pairwise Nei's genetic distances (D) based on ISSR polymorphism between studied species of the H. gmelinii group.

alt-text: Table 3

\begin{tabular}{|c|c|c|c|}
\hline & H. gmelinii & H. chaiyrakanicum & H. setigerum \\
\hline H. gmelinii & - & 0.115 & 0.046 \\
\hline H. chaiyrakanicum & - & - & 0.109 \\
\hline H. setigerum & - & - & - \\
\hline
\end{tabular}

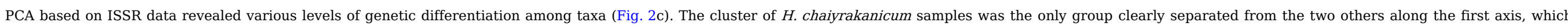

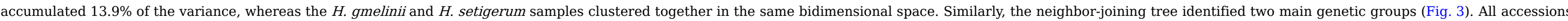

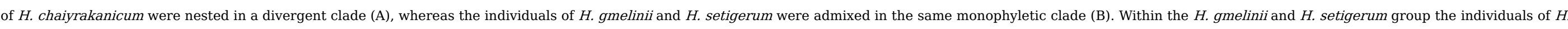

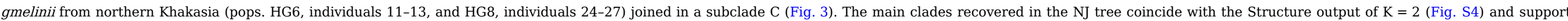




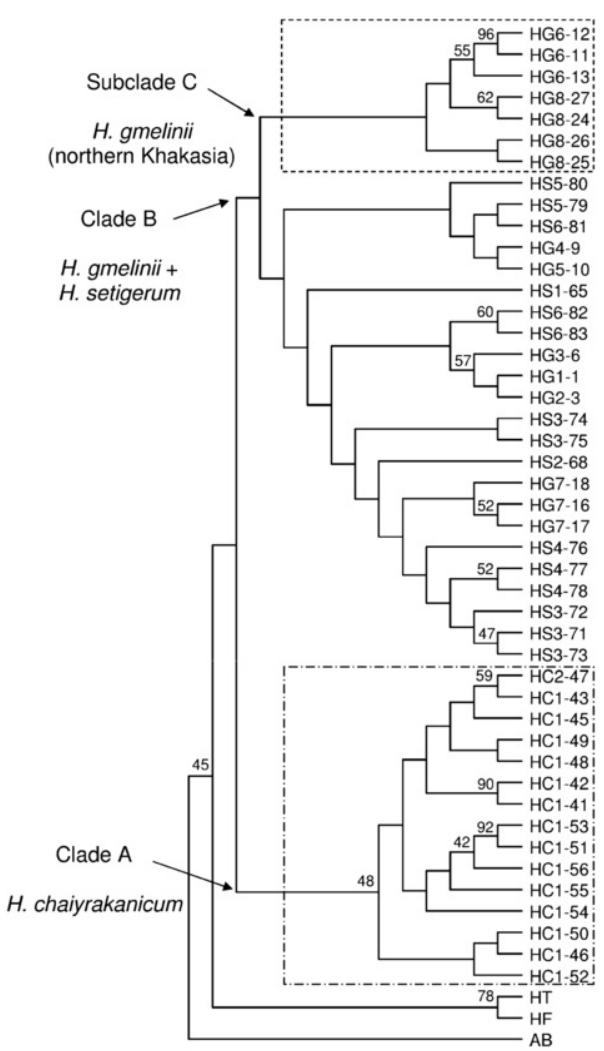

$-$

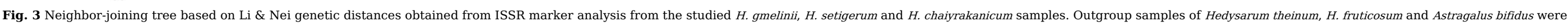
used to root the tree. Bootstrap support values greater than $40 \%$ are indicated on branches.

\section{alt-text: Fig. 3}

\section{Discussion}

\subsection{Taxonomic value of morphological and carpological characters in the classification of the $\mathrm{H}$. gmelinii complex taxa}

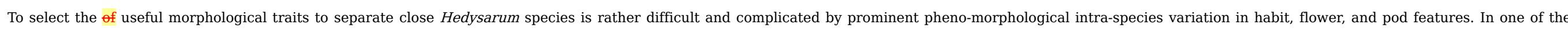

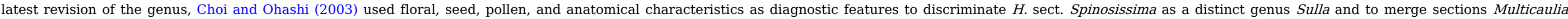

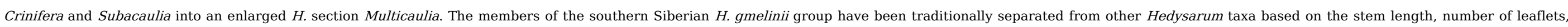

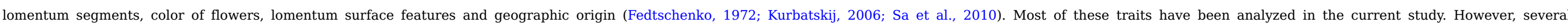

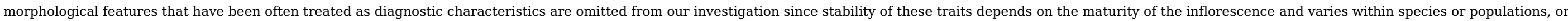
even within a single plant. The neglected traits are the color of flower, length of inflorescence, number of flowers and lomenta per inflorescence, and number of segments per lomentum. 


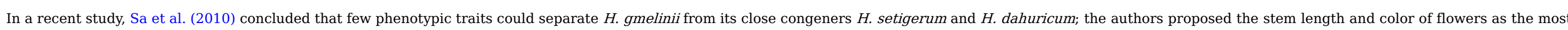

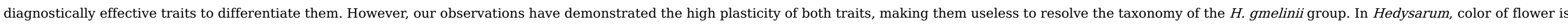

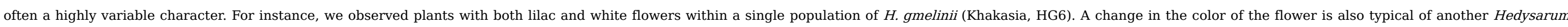

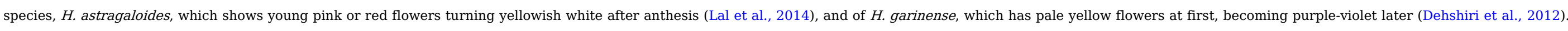

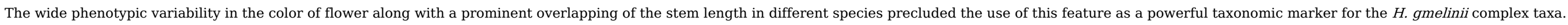

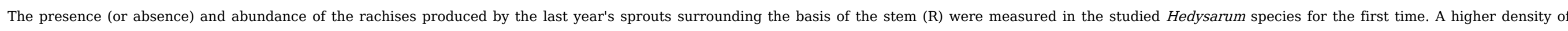
rachises in H. chaiyrakanicum (Table S1) supports this trait as a diagnostic feature for resolving the taxonomy of short-stemmed Hedysarum species.

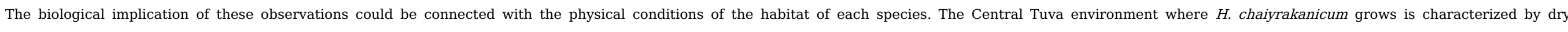

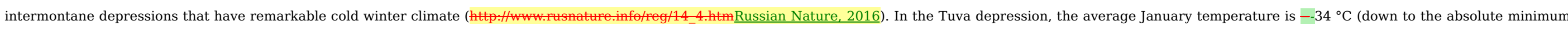

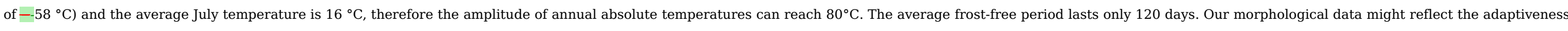

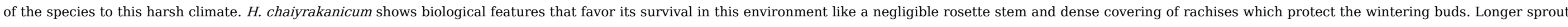
vs less vegetative biomass (smaller number of leaflets) compensate for the short stem and facilitate the production and effective dispersal of seeds during a short reproductive season.

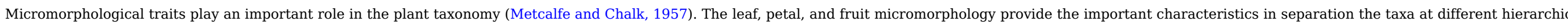

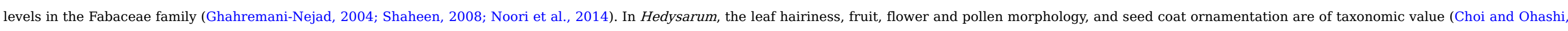
2003; Ghanavati and Amirabadizadeh, 2012; Dural and Citak, 2015) and have been used for the identification and description of new species (Sa, 2007).

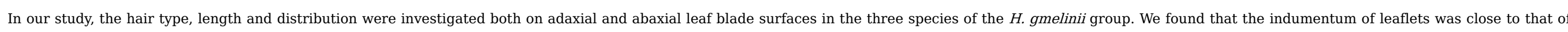

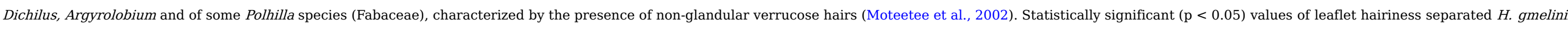

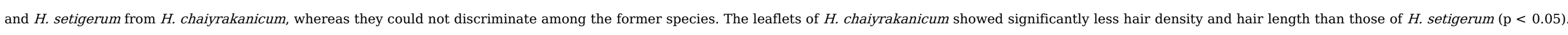

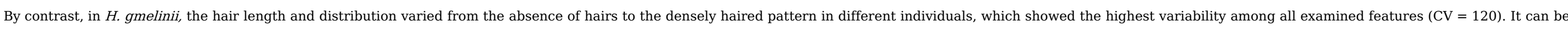
concluded that this trait could not be used to characterize the later species.

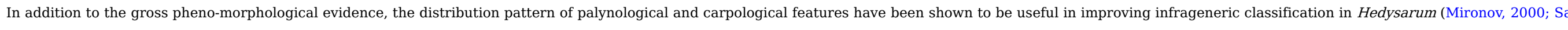

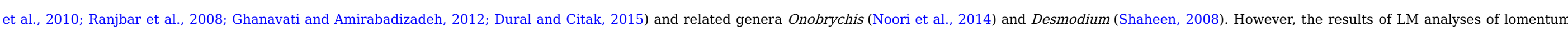

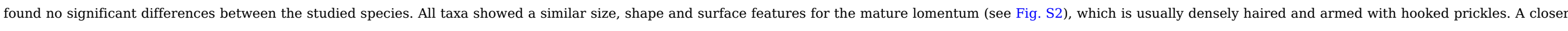

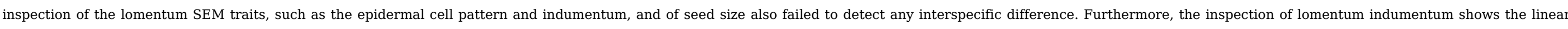
warts covered with trichomes (Fig. S3l) as in H. pannosum, a less related species from sect. Crinifera (Boiss.) B. Fedtsch. (Dural and Citak, 2015).

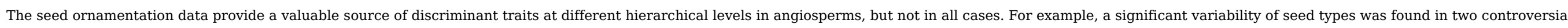

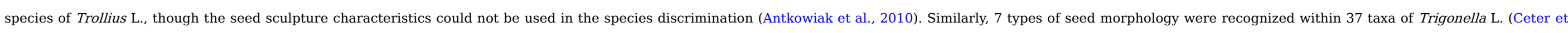
al., 2012), however, seed characteristics did not provide any considerable information to separate the species even at sectional level.

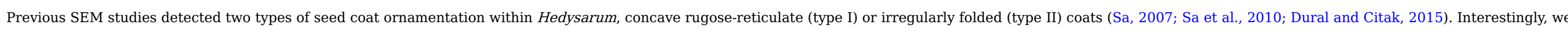

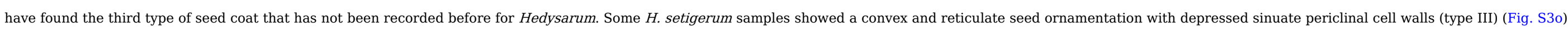

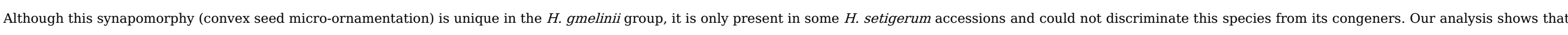

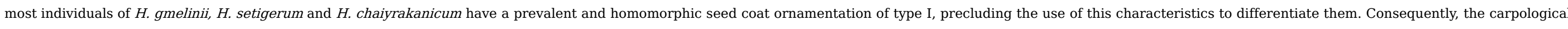
features have limited application in the taxonomy of the H. gmelinii group species.

\subsection{Genetic ISSR markers support phenotypic differences and the separation of $\boldsymbol{H}$. chaiyrakanicum from $\boldsymbol{H}$. gmelinii sensu lato} (incl. $\mathrm{H}$. setigerum) 


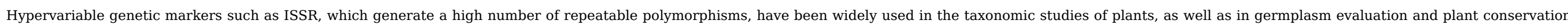

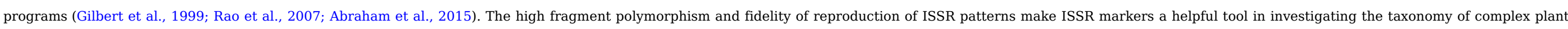

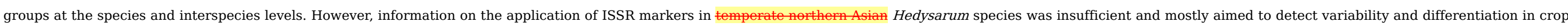

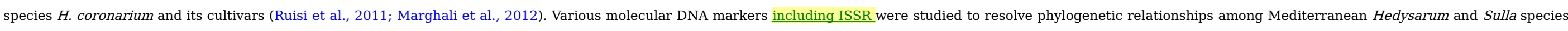
(Chennaoui-Kourda et al., 2007; Marghali et al., 2014).

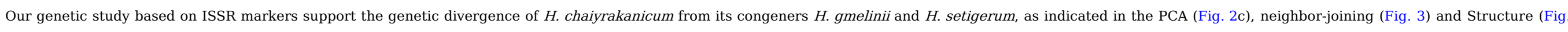

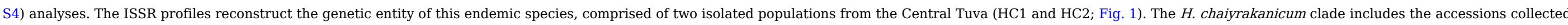

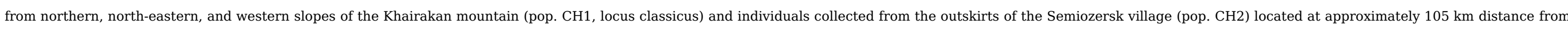
Khairakan and separated from it by the Kurtushibinsky mountain ridge.

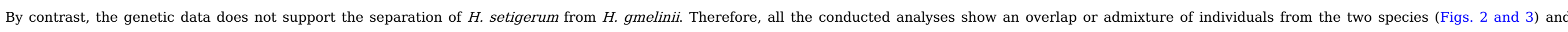

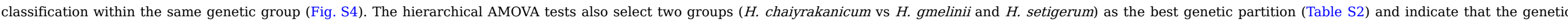

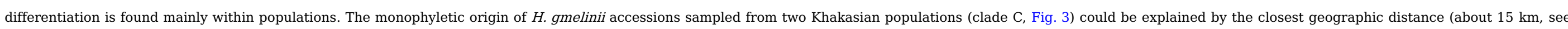
Fig. 1) between them, which does not preclude the pollinators' migration, facilitating the genetic drift and therefore it may prevent population diversification.

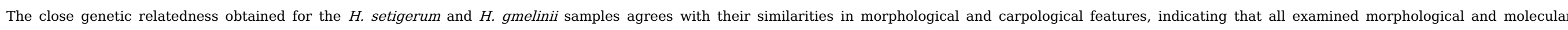

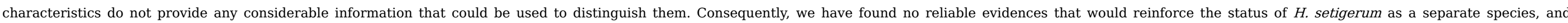

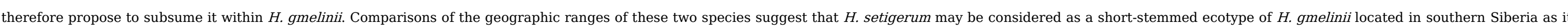

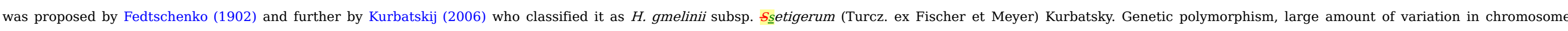

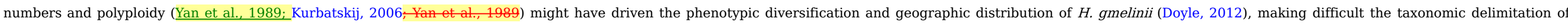

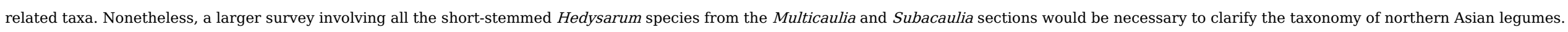

\section{Funding}

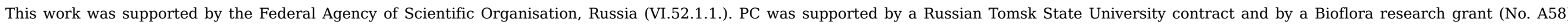
cofinanced by the Spanish Aragon Government and the European Social Fund.

\section{Conflict of interest}

The authors declare that they have no conflict of interest.

\section{Acknowledgements}

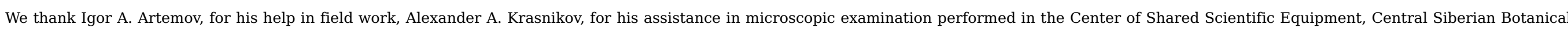
Garden SB RAS, Novosibirsk, and Inessa Yu. Selyutina and Nina A. Karnaukhova, for providing the plant material.

\section{Appendix A. Supplementary data}

Supplementary data related to this article can be found at http://dx.doi.org/10.1016/j.bse.2016.10.001.

\section{Uncited references}

Cordoba et al., 2013; RussianNature.

\section{References}

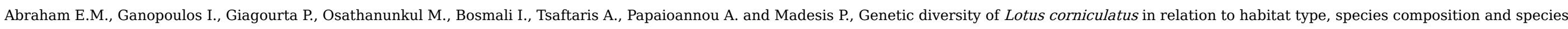


diversity, Biochem. Syst. Ecol. 63, 2015, 59-67.

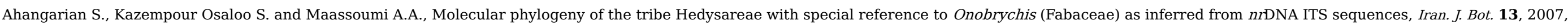
64-74.

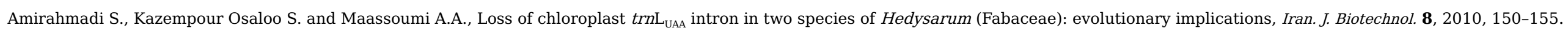

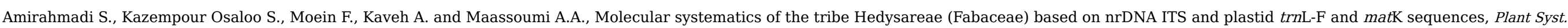

Evol. 300, 2014, 729-747, http://dx.doi.org/10.1007/s000606-013-0916-5.

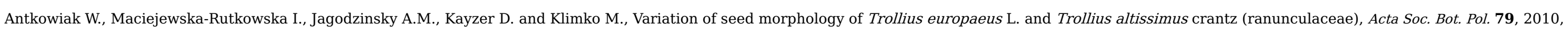

117-123, http://dx.doi.org/10.5586/asbp.2010.016.

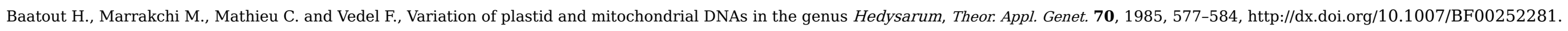

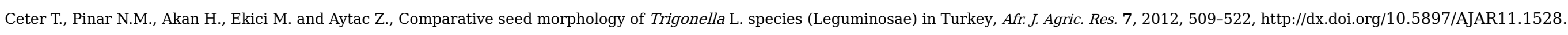

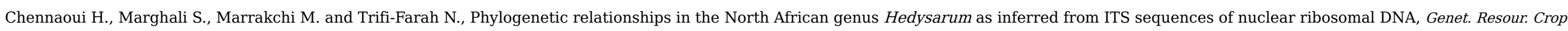
Evol. 54, 2007, 389-397, http://dx.doi.org/10.1007/s10722-006-0001-9.

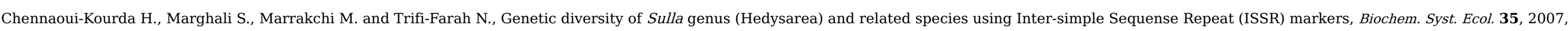
682-688.

Cherkasova E.S., Chromosome numbers of rare species of the Hedysarum (Fabaceae), Bot. Zhurn. (Moskow Leningrad) 94, 2009, 135-138, (In Russia]).

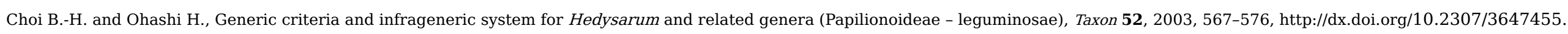

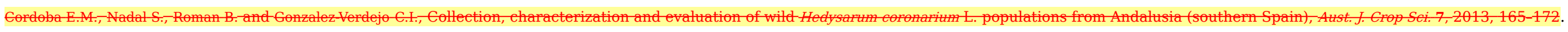

Dehshiri M.M., Hedysarum kalatense sp. nov. (Fabaceae) from Iran, Nord. J. Bot. 31, 2013, 208-212, http://dx.doi.org/10.1111/j.1756-1051.2012.01535.x.

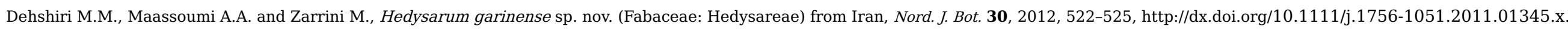

Doyle J.J., Polyploidy in legumes, In: Soltis P. and Soltis D., (Eds.), Polyploidy and Genome Evolution, 2012, Springer; Heidelberg, 147-180.

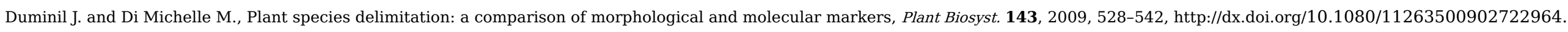

Dural H. and Citak B.Y., Morphology and anatomy of Hedysarum pannosum (Boiss.) Boiss. (Fabaceae), Acta Bot. Croat. 74, 2015, 19-29, http://dx.doi.org/10.1515/botcro-2015-0009.

Earl D.A. and von Holdt B.M., Structure Harvester: a website and program for visualizing Structure output and implementing the Evanno method, Conserv. Genet. Resour. 4, 2012, 359-361,

http://dx.doi.org/10.1007/s12686-011-9548-7.

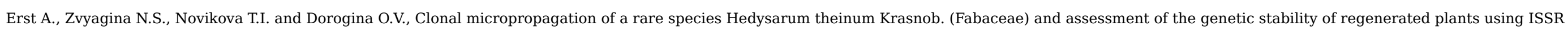
markers, Russ. J. Genet. 51, 2015, 158-162.

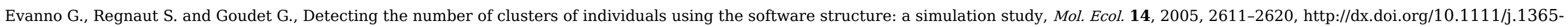
294X.2005.02553.x.

Excoffier L.G., Laval L.G. and Schneider S., Arlequin ver. 3.0: an integrated software package for population genetics data analysis, Evol. Bioinform. Online 1, $2005,47-50$.

Fedtschenko B.A., The genus Hedysarum, Acta Horti. Petrop. 19, 1902, 183-342.

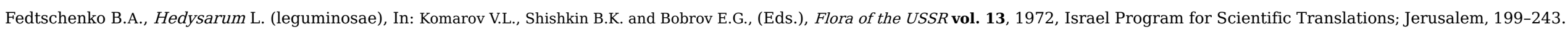




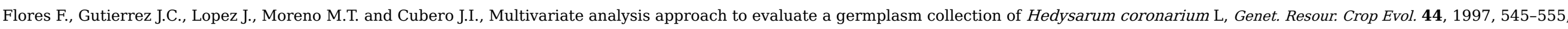
http://dx.doi.org/10.1023/A:1008682019883.

Ghahremani-Nejad F., Value of trichome characteristics for the separation of bifurcating hairy Astragalus L. (Fabaceae) at the sectional level, Turk. J. Bot. 28, $2004,241-245$. Ghanavati F. and Amirabadizadeh H., Pollen grain morphology in iranian Hedysareae (Fabaceae), C. B. J. 2, 2012, 25-33.

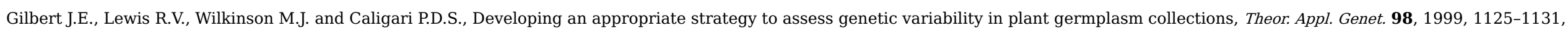
http://dx.doi.org/10.1007/s001220051176.

Hammer O., Harper D.A.T. and Ryan P.D., PAST: paleontological Statistics software package for education and data analysis, Palaeontol. Electron 4, $2001,9$.

Krasnoborov I.M., Azovtsev G.R. and Orlov V.P., A new species of the genus Hedysarum (Fabaceae) from the southern Siberia, Bot. Zhurn. (Moskow Leningrad) 70, 1985, 968-973, (In Russian).

Kurbatskij V.I., Novyi vid kopeechnika (Hedysarum L.) iz Tuvy (The new Hedysarum species from Tuva), Syst. Notes Herb. TSU 88, 1990, 6-7, (In Russian).

Kurbatskij V.I., Genus Hedysarum L., In: Polozhij A.V. and Malyshev L.I., (Eds.), Flora of Siberia. Fabaceae (Leguminosae) vol. 9, 2006, Science Publishers; Enfield, 151-164.

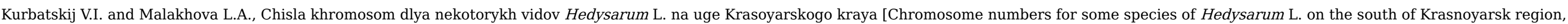
Russia (Minusinsk steppe)], Syst. Notes Herb. TSU 93, 2003, 12-13, (In Russian).

Lal K., Kushwaha A.K. and Chaudhary L.B., Taxonomic notes on Hedysarum astragaloides (Fabaceae), J. Jpn. Bot. 89, 2014, $230-235$.

Ledebour C.F., Mém. Acad. Imp. Sci. St. Pétersbg. Hist. Acad. 5, 1812, 551.

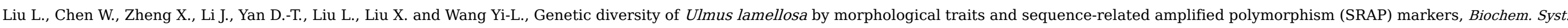
Ecol. 66, 2016, 272-280.

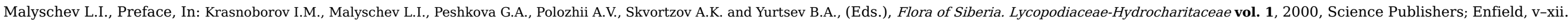

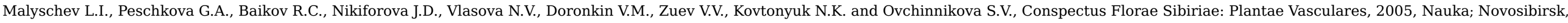
5, (In Russian).

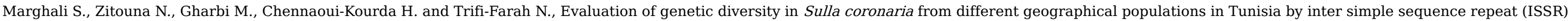
Afr. J. Biotechnol. 11, 2012, 12158-12166, http://dx.doi.org/10.5897/AJB12.530.

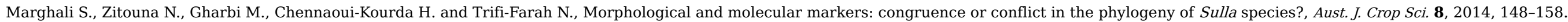
Metcalfe C.R. and Chalk L., Anatomy of the Dicotyledons vol. 1, 1957, Clarendon Press; Oxford, 476-535.

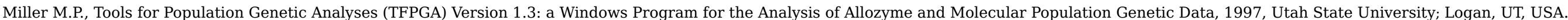

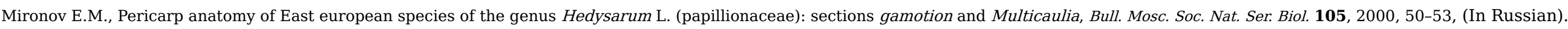

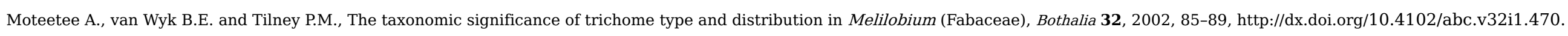

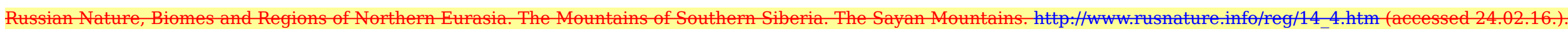
Nei M., Genetic distance between populations, Am. Nat. 106, 1972, 283-292, http://dx.doi.org/10.1086/282771 .

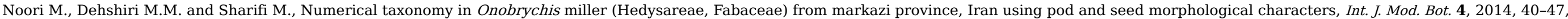
http://dx.doi.org/10.5923/j.ijmb.20140402.02. 


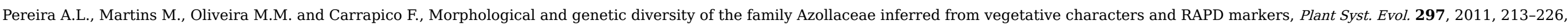
http://dx.doi.org/10.1007/s00606-011-0509-0.

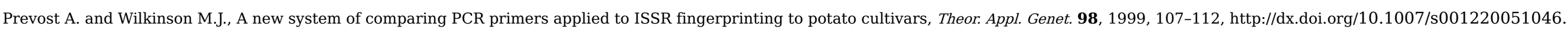
Pritchard J.K., Stephens M. and Donnelly P., Inference of population structure using multilocus genotype data, Genetics 155, 2000, 945-959.

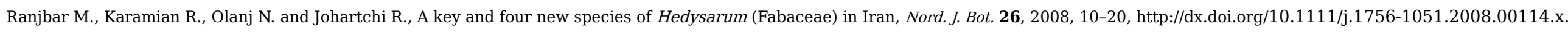

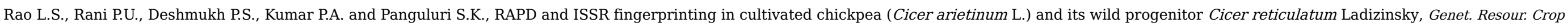
Evol. 54, 2007, 1235-1244, http://dx.doi.org/10.1007/s10722-006-9104-6.

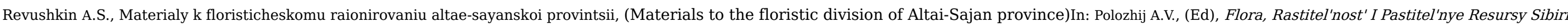
(Flora, Vegetation and Vegetative Resources of Siberia), 1987, Tomsk State University Press; Tomsk, 32-46, (In Russian).

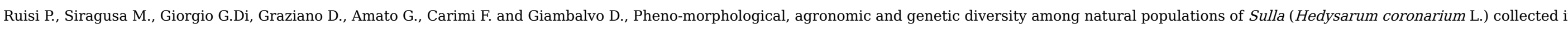
Sicily, Italy, Genet. Resour. Crop Evol. 58, 2011, 245-257, http://dx.doi.org/10.1007/s10722-010-9565-5.

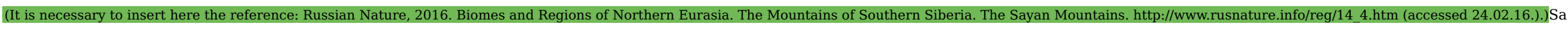

R., Hedysarum jaxartucirdes (Fabaceae), a new species from Xinjiang, China. Ann. Bot. Fenn. 44, 2007, 157-159.

Sa R., Su D. and Debreczy Z., Taxonomic notes on the Hedysarum gmelinii complex (Fabaceae), Ann. Bot. Fenn. 47, 2010, 51-58, http://dx.doi.org/10.5735/085.047.0106.

Shaheen A.S.M., Morphological and anatomical investigation in Desmodium tortuosum (Sw.) DC. (Fabaceae): a new addition to the Egyptian flora, Bangl. J. Plant Taxon. 15, 2008, 21-29,

http://dx.doi.org/10.3329/bjpt.v15i1.908.

Takhtadjan A.L., Floristic Regions of the World, 1986, University of California Press; Berkeley, Los Angeles, London.

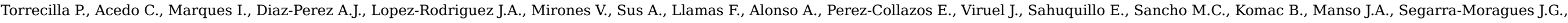

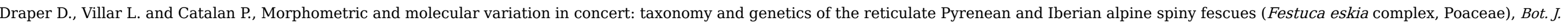

Linn. Soc. 173, 2013, 676-706, http://dx.doi.org/10.1111/boj.12103.

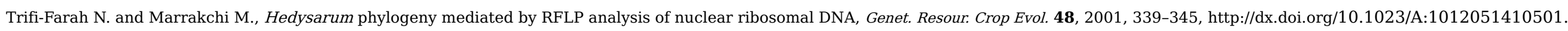

Vdovitchenko M.Y., Kuzovkina I.N., Paetz C. and Schneider B., Formation of phenolic compounds in the roots of Hedysarum theinum cultured in vitro, Russ. J. Plant Physl. 54, 2007, 604-613,

http://dx.doi.org/10.1134/S1021443707040164.

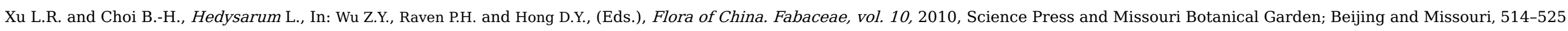

Yakovlev G.P., Sytin A.K. and Roskov Y.R., Legumes of Northern Eurasia: a Check-list, 1996, Royal Botanical Gardens; Kew, 379-407.

Yan G.X., Zhang S.Z., Yan J.F., Fu X.Q. and Wang L.Y., Chromosome numbers and geographical distribution of 68 species of forage plants, Grassl. China [Zhongguo Caoyuan] 4, 1989, 53-60.

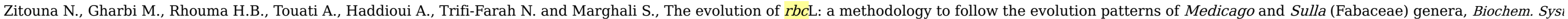
Ecol. 57, 2014, 33-39.

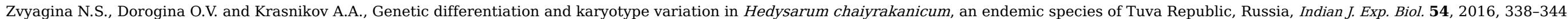

\section{Appendix A. Supplementary data}

The following is the supplementary data related to this article: 


\section{Highlights}

- The H. chaiyrakanicum is well discriminated by its ISSR and morphological profiles.

- Our study provided no evidences for the separation of H. gmelinii and H. setigerum.

- H. setigerum should be treated as a subspecies of H. gmelinii.

- Based on the Nei' standard coefficients, the species of H. gmelinii group have evolved recently.

- The ISSR profile is found to be an important diagnostic feature in biosystematics of Hedysarum.

\section{Queries and Answers}

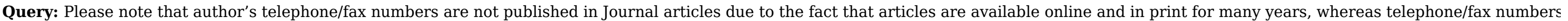
are changeable and therefore not reliable in the long term.

Answer: Fax number: +73833301986

Query: The citation “Kurbatsky (1990), Zitouna et al., 2012, Nei's (1972)" have been changed to match the author name/date in the reference list. Please check.

Answer: All these changes are correct.

Query: Please supply the year of publication.

Answer: 2016

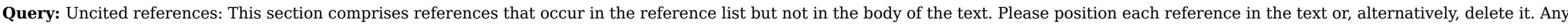
reference not dealt with will be retained in this section. Thank you.

Answer: The reference "Cordoba et al., 2013" was deleted; the reference "Russian Nature" was corrected and replaced within the reference list according the alphabet order.

Query: Please confirm that given names and surnames have been identified correctly.

Answer: Yes

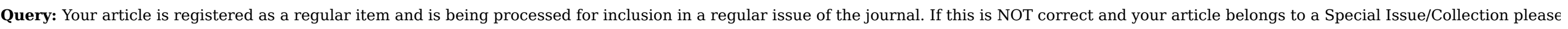
contact s.sekar@elsevier.com immediately prior to returning your corrections.

Answer: Yes 